\title{
EXPLORING GROWTH LINKAGES IN A SOUTH AFRICAN SMALLHOLDER FARMING AREA
}

\author{
S. Ngqangweni' ${ }^{1}$ J.F. Kirsten ${ }^{1}$ and C. Delgado?
}

Only recently have major research efforts been put into investigating the potential of South African smallholder ngriculture to stimulate economic growth, crente' ('mployment and allevinte poverty in the black rural areas. Following on some of the pioneer work on this subject, this paper applies the conccpt of 'grouth linkage's' in the anthlysis of smallholder agriculture production in Eastern Cape. It shous that mu injection of smalliolder income into the rural economy will result in significunt rural income growth beyond the initial injection. Exploitation of this potentinl would require a deliberate policy foctus to aid agricultural transformation in the smallholder farming arcas. Such support should be directed towards activities in which suallholder farmers have a comparative advanlage, such as in citrus and livestock in Enstern Cape. Such a policy will then favor autonomous development of rural non-tradables, such as rural services, local construction matcrials, and perishable prepared foods.

\section{INTRODUCTION}

Pioneer research on smallholder agriculture in South Africa has revealed that, owing to their labour-intensity, small-scale farms have potential to contribute towards reduction of rural poverty and inequality (Lipton, Ellis and Lipton, 1996; Van Zyl, 1996). Other recent research has also shown that some smallholder activities in South Africa make efficient use of scarce resources (Ngqangweni, Kirsten, Lyne and Hedden-Dunkhorst, 1999). These findings provide an alternative perception to the pessimistic view that small farms would create few additional rural livelihoods (see for example De Klerk, 1996; Eckert, 1996; Kirsten, 1996 and Lyne \& Ortmann, 1996).

This paper follows on the above-mentioned research and introduces the concept of 'growth linkages' in the analysis of smallholder agriculture. It presents results of an investigation into the dynamics of rural income and employment expansion through multiplier effects generated from tradable smallholder agriculture in the Eastern Cape. Specifically, this study estimates how much additional growth could be generated in the rural areas from stimulating the non-tradable sectors in the rural economy through injection of

1 Department of Agricultural Economics, Extension and Rural Development, University of Pretorin, Pretoria 0002.

2 International Food Policy Resenrch Institute, Wasinington, D.C., USA. 
a unit of new income from the tradable sectors. This new' income originates from technological progress or policy changes affecting the profitability of production of rural tradables (Mellor, 1966), and in particular agricultural commodities. As will be seen below, tradability is a concept that is defined with respect to a specific area of interest. For this paper, the area of interest is a smallholder rural area of Eastern Cape inhabited by previously disadvantaged persons. The objective is to examine how to set in motion growth that will have spin-off benefits to these areas.

Similar studies have been conducted elsewhere in Africa and in Asia (Haggblade, Hazell \& Brown, 1987 and Delgado ol al., 1998). These studies have demonstrated that increasing small-farm agriculhural production through agricultural intensification can boost regional employment by creating a market for local goods that would otherwise have been sold only locally because of high transaction costs. The spin-off effects of growth in rural tradables, expressed as "growth multipliers", have been found to be quite significant in these countries. Such findings have called attention to a required policy focus on getting tradable agriculture moving so as to stimulate rural growth potential in developing economies.

\section{METHODOLOGY}

This study utilized data collected with the use of structured questionnaires over three rounds in 1998. A total of 100 randomly sampled households were interviewed in two villages in Middledrift district in central Eastern Cape. The sample was subdivided such that 50 households were survered in each of the two chosen villages, namely rural KwaNdindwa and the relatively more 'urbanized' village of Ann Shaw. The survey had two immediate main objectives. The first objective was to examine how increased rural incomes would be spent on a mix of tradable and non-tradable farm and non-farm good service categories. The second goal was to assess the potential for these expenditure patterns to generate growth multipliers in the rural areas. The analysis estimated modified Working-Leser regressions (Hazell and Röell, 1983; Delgado et al., 1998) to estimate marginal budget shares (MBS) for a typical rural household in each specified good/service category, based on mean values from the household survey. Growth multipliers were estimated expeditiously by ignoring the use of non-tradable inputs, leading to a very simple algorithm. 


\subsection{The household expenditure model}

A modified Working-Leser model of the following form was employed for estimation:

$$
S_{i}=\beta_{i}+\alpha_{i} / E+\gamma \log E+\Sigma_{i}\left(\mu_{i} Z_{1} / E+\lambda_{1 !} Z_{1}\right)
$$

Where:

$S_{l}$ is the share of commodity $i$ in total expenditure

$E$ is total consumption expenditure

$E_{i}$ is expenditure on commodity $i$

$Z$, are household characteristic variables, and

$\alpha_{i}, \beta_{i,} \gamma_{\nu} \mu_{i j,} \lambda_{i}$, are constants

The marginal budget share $\left(M B S_{1}\right)$, average budget share $\left(A B S_{1}\right)$ and expenditure elasticity $\left(\xi_{i}\right)$ for the $i$ th commodity are as follows:

$$
\begin{aligned}
& M B S_{i}=\partial E_{i} / \partial E=\beta_{i}+\gamma_{i}(1+\log E)+\Sigma \cdot \lambda_{1 i} Z_{j} \\
& A B S_{i}=S_{i} \\
& \xi_{i}=M B S_{i} / A B S_{i}
\end{aligned}
$$

These equations are evaluated at sample mean values for the average household for $E$ and the $Z_{j}$. But across expenditure groups (say upper and lower expenditure halves, as done in this study), then $E$ and the $Z$, were assigned their mean values for relevant halves.

\subsection{The growth multiplier model}

Growth multipliers are a meásure of how much extra net income growth can be derived in the rural areas from stimulating production in the non-tradable sectors through new effective demand from a unit of new income from the tradable sectors. A multiplier is a numerical derivation from a regional model that typically incorporates household demands and intermediate demands between sectors. Conceptually, computing a multiplier requires a definition of what is inside the region of interest and what is outside, and spin-off effects are limited to those inside the zone. In Middledrift, the region of interest was restricted to local administrative boundaries. Definition of a region of interest makes possible the identification of consumption items that are tradables and non-tradables with respect to the region of interest. 
For present purposes, a non-tradable is a good whose current local price is determined by local supply and demand, regardless of modest price movements outside the region of interest. Such goods are typically not traded with points outside the region of interest, and are not close substitutes in consumption with items that are. By definition, all services are non-tradables. Perishable prepared foods are often non-tradables in rural areas, though not in all places. Tradability or lack of it is a characteristic of the local market for a given item and not of the good. Tradables are goods whose local free market price is determined primarily by factors outside the region of interest.

An important difference between tradables and non-tradables thus defined is that an increase in local consumer demand for tradables does not add further to local incomes. This is because the increased consumption is either imported to the region of interest, or local production that was exported is now diverted to local consumption. However, an increase in local consumer demand for non-tradables increases the demand for an item that cannot be imported and is not being exported (by definition). Provided that local resources are not fully employed and are available for work, the new demand for non-tradables creates net additions to local employment and incomes. This illustrates a major assumption of lirkage analysis, that the elasticity of supply of non-tradable items consumed locally is elastic (Delgado ct al., 1998). Failing this, increased demand for non-tradable consumer items stemming from increased incomes in the area of interest will just lead to inflation.

After subjective classification of local consumer items into tradables and nontradables, this study aggregated the goods and services identified into four main categories: farm tradables, non-farm tradables, farm non-tradables and non-farm non-tradables. "Farm" goods originate on-farm. These include horticultural, crop, livestock items produced on household land. "Non-farm" goods on the other hand originate off-farm. These include all consumption durables and non-durables.

Estimating the full regional multiplier requires including new demands for non-tradable inputs, in addition to new demands for non-tradable final goods. However, this greatly complicates the calculations. For simplicity, we ignore non-tradable intermediate inputs, which will bias our results downwards by about 5-10 percent, based on simulations in other African countries (Delgado ef al., 1998). We also ignore the fact that our simple formulation in fact assumes that all additional demand for non-tradables goes fully into increased production (and none of it into increased relative prices for non-tradables, implying a perfectly elastic supply of non-tradables). This has been shown elsewhere to bias multiplier estimates upwards by $20-30$ percent, which 
more than offsets the downward bias. On balance, our simple methodology may slightly overestimate true multipliers, but by no more than 20 percent.

The simple multiplier is easy to see if we start with the amount of spending left over írom an income injection after spending on tradables (which, recall, do not add to net local employment) and savings are netted out: (1 - MBS tradables -s), where " $s$ " is the share of income saved. This is then repeated multiplicatively " $t$ " times, where $t$ is the number of times the income is respent in the local community. Since the parameters are both positive and less than unity, the multiplier is the solution to an infinite series:

Multiplier $=\frac{\left(1-\text { MBS tradable }-s^{t}\right.}{(1-\text { MBS nontradables }+s)}$

remembering that : $1-$ MBS tradables $=$ MBS nontradables.

\section{GROWTH LINKAGES IN MIDDLEDRIFT, EASTERN CAPE}

Table 1 below summarizes the growth multipliers calculated from the Middledrift household analysis.

Table 1: Estimated total extra production income from re-spending effects of R1 extra income from production of tradables in Middledrift, Eastern Cape

\begin{tabular}{|l|c|c|c|c|}
\hline \multicolumn{1}{|c|}{ Sample category } & $\begin{array}{c}\text { Tradable } \\
\text { sector }\end{array}$ & $\begin{array}{c}\text { Farm } \\
\text { non-tradable }\end{array}$ & $\begin{array}{c}\text { Non-farm } \\
\text { non-tradable }\end{array}$ & $\begin{array}{c}\text { Total } \\
\text { Multiplier }\end{array}$ \\
\hline Overall sample & 1.00 & 0.35 & 0.63 & 1.98 \\
\hline Lower Expenditure 50\% & 1.00 & -0.35 & 0.16 & 0.81 \\
\hline Upper Expenditure 50\% & 1.00 & -0.14 & 1.22 & 2.08 \\
\hline Rural sample & 1.00 & 0.06 & 0.92 & 1.98 \\
\hline Small Town Sample & 1.00 & 0.21 & 0.33 & 1.53 \\
\hline
\end{tabular}

The figures in the above table show the total net additions to average household income in South African Rands that result from an initial shock of R1.00 in the local tradable farm or non-farm sectors. The sources of growth have been decomposed into new spending on farm and non-farm demand constrained non-tradable goods. The sample has also been subdivided into rural and small town halves, as well as into lower and upper expenditure halves. 
The "overall sample" row in the ahove table shows a R1.00 increase in household incomes through an outside positive effect (for example, a technological progress or policy change) affecting local tradables. It also shows that such an increase will lead to R0.35 of additional income from spending on farm non-tradables, and to R0.63 of additional income from spending on non-farm non-tradables. This means a total multiplier of R1.98, of which R0.98 is the net extra growth from spending on demand-constrained items.

The "lower expenditure" row represents those households who spend relatively less on goods and services. The total multiplier for this group is the lowest at R0.81. Most of this could be attributable to a negative contribution (-R0.35) from the farm non-tradable sector. This suggests that as lower income people get more income from outside the zone, at the margin, they shift somewhat out of consuming non-tradables, which lowers the net income gain. On the other hand the "upper expenditure" group boosts the highest total multiplier of $\mathrm{R} 2.08$. For this group, the negative contribution from the farm non-tradable sector is compensated for by a large contribution of R1.22 from the non-farm non-tradable sector.

A particularly interesting phenomenon emerges from these results in the "lower expenditure" and "upper expenditure" rows. A result of income respending on farm non-tradables in both sample categories yields "negative" multipliers. This is only possible when, instead of producing increased income, demand-constrained non-farm items $u s e$ up such new spending. It is interesting to note that such an occurrence appears to be unique to farm nontradables. It is probably confirmation of findings from initial linkages work in Africa that consumption linkages from agriculture are particularly weaker than those from the non-agricultural sector (Delgado, et al., 1998). It could be clearly seen, however, that such a supposed loss of income is compensated for by new gains from spending in non-farm non-tradable items.

Table 1 above illustrates a number of other interesting facts. First, 'local' level linkages in South Africa seem to be remarkably close to those reported for the rest of Sub-Saharan Africa, as summarized in Delgado et al. (1998). Second, it shows that multiplier figures for the rural sample are almost a third more than those of the urbanized households. This suggests that targeting income to smallholders in the region will have significantly greater spin-off effects than channeling the same income to township dwellers in the region. Third, overall multipliers from the non-farm sector in Middledrift are higher than those from the farm sector. In fact the farm sector multipliers constitute only 18 percent of the composition of the total multiplier compared to 32 percent of 
the non-farm sector. This is a much lower share of multipliers than seen elsewhere in rural Sub-Saharan Africa (Delgado 't al., 1998). The implication is that in Middledrift, higher incomes from increased production of farm tradables will impact primarily on the development of rural service industries and local non-farm enterprises.

\section{DISCUSSION AND CONCLUSIONS}

A number of policy implications follow from this research. First, although only based on the 'local' level, the findings clearly show that rural growth linkages in South Africa are particularly strong. They match those recorded from similar studies in elsewhere in Africa and Asia. This emphasizes a need for demand-led growth policies in the rural areas of South Africa. There is very significant extra growth potential through boosting rural incomes, which in tum would stimulate demand for non-tradable goods and services. Underemployed resources would then be brought into production.

The existence of these consumption-side growth linkages can easily be seen in many smallholder areas of South Africa, and are probably due to the significant inflow of pension income and other remittances. This cash inflow has helped make viable small-scale brick factories, rural stores, and so forth, even in remote local areas. However, it will be vital to gradually increase the share of this form of growth that comes from renewable sources within the local area, such as production for sale outside the local area of agricultural items. This will lessen the dependency of these areas on transfer payments from cities.

Second, most of the extra growth in non-tradable sectors would come from spending on non-farm goods and services. Rural consumers prefer to spend their net income increases " on non-farm non-tradables such as services (transport, education, and health). Policy should therefore continue to pay attention to increasing supply-responsiveness of these items, but realize that these items can only survive if incomes are growing from some other source. They are not a substitute for an economic growth strategy.

Third, and last, there is always the thorny problem of identifying the tradable agricultural commodities in which smallholders possess a comparative advantage and have a potential to act as the initial stimulus for the nontradable non-farm sector. By the definition of comparative advantage, every smallholder has one, even if he or she does not have an absolute advantage in any agricultural activity relative to commercial farming. What is needed are activities in which it is possible for smallholders to make a return 
commensurate with there other options. While we have not assessed this here, evidence from Ngqangweni, t' al. (1999) points towards livestock and citrus in the Eastern Cape province, and sugar cane and timber in KwaZulu-Natal, as activities with this potential. Investments in smallholder support services for these activities, such as extension and training, credit, infrastructure, research and information are therefore warranted in a "multiplied" sense, since the returns are twice as great as the direct returns in production of the original items.

\section{REFERENCES}

DE KLERK, M. (1996). The sustainable livelihood creation potential of smallscale horticulture in the Western Cape. In M. Lipton, M. de Klerk and M. Lipton (eds). Land, Labour and Livelihoods in Rural South Africn. Volume 1. Durban: Indicator Press. pp. 201-244.

DELGADO, C.L., HOPKINS, J., \& KELLY, Y. (WITH OTHERS). (1998). Agricultural grouth linknges in sub-Snimran Africu. IFPRI Research Report No. 107. Washington, D.C.: IFPRI.

ECKERT, J. (1996). Fifty hectares and freedom: Field crop options for smallscale farmers in the Western Cape. In M. Lipton, M. de Klerk and M. Lipton (eds). Land, Labour and Livelihoods in Rural South Africa. Volume 1. Durban: Indicator Press. pp. 245-274.

HAGGBLADE, S.; HAZELL, P.B.R. \& BROWN, J. (1987). Farm/non-form linkages in rural sub-Saltarm Africa: Empirical covidence and policy implications. Discussion Paper 67. Washington, D.C.: The World Bank.

HAGGBLADE, S. \& HAZELL, P.B.R. (1989). Agricultural technology and farm-nonfarm growth linkages. Agricultural Economics (3): 345-64.

HAZELL, P.B.R. \& HOJJATI, B. (1995). Farm/non-farm growth linkages in Zambia'. World Development, 4(3):406-35.

HAZELL, P.B.R. \& ROËLL, A. (1983). Rurnl grouth linknges: Household expenditure patterns in Malaysia and Nigerin. IFPRI Research Report No. 41. Washington, D.C.: IFPRI.

KIRSTEN, J. (1996). The potential for creating additional rural livelihoods in agriculture and the rural non-farm sector in semi-arid areas. A case study in the Northern Province'. In M. Lipton, Ellis and M. Lipton (eds). Land, Labour 
and Livelihoods in Ruml South Africn. Volume 2. Durban: Indicator Press. pp. 303-334.

LIPTON, M., ELLIS, F. \& LIPTON, M. (1996). Introduction. In M. Lipton, F. Ellis and M. Lipton (eds). Land, Lubour ant Livelihoots in Rural South Africa. Volume 1. Durban: Indicator Press. pp. v-xvii.

LYNE, M.C. \& ORTMANN, G.F. (1996). Estimating the Potential for Creating Additional Livelihoods on Commercial Farmland in KwaZulu-Natal'. In M. Lipton, M. Ellis and M. Lipton (eds). Land, Labour mid Livelihoods in Rural South Africn. Volume 2. Durban: Indicator Press. pp. 59-76.

MELLOR, J.W. (1966). The economics of agricultural development. Ithaca, NY: Cornell University Press.

NGQANGWENI, S., KIRSTEN, J.F. LYNE, M.C. \& HEDDEN-DUNKHORST, B. (1999). Measuring smallholder comparative advantage in three South African provinces. Agrekon, 38 (Special issue):235-242.

VAN ZYL, J. (1996). The farm size-efficiency relationship. In J. van Zyl, J. Kirsten and H.P. Binswanger (Eds). Agricultural Land Reform in South Africa: Policies, Markets and Mechanisms. Cape Town: Oxford University Press. Pp. 259-309. 